\title{
Denial of Human Superiority Over Nature as the Denial of the Value of Nature
}

\section{Zaprzeczenie wyższości człowieka względem przyrody jako zaprzeczenie wartości przyrody}

\author{
Mariya Yarema \\ Ukrainian Catholic University, Lviv, Ukraine \\ ORCID https://orcid.org/0000-0003-2029-4766•maria.yarema@ucu.edu.ua \\ Received: 14 Sep, 2021; Revised: 24 Oct, 2021; Accepted: 5 Nov, 2021
}

\begin{abstract}
Ecology as a science today, mainly rejects anthropocentrism in favour of nonhuman-centred ethics. Such rejection is propagated as a proper valuing of nature, while the human-centred eco-theories are considered to be the theoretic basis for the exploitation and destruction of nature by humans. The main purpose of some nonhuman-centred ecologic theories is to reduce the growth of the human's population because the people's existence, totally, is seen as a cause of ecological disasters, and even social problems. The aim of the article is to show that human beings are, in reality, the only living organisms on Earth, able to take care about nature as it deserves. The main problem is incorrect behaviour with nature, not a big amount of people living on the Earth. The ecological disasters, at the same time, are connected not only with humans' irresponsible conduct, but with the natural forces that are independent from human activity, but that does not deprive people from the task to take responsibility for their environmental behaviour.
\end{abstract}

Keywords: environmental ethics, stewardship of nature, ecological myths

Streszczenie: Współczesne nurty ekologii najczęściej odrzucają antropocentryzm na rzecz etyki nieantropocentrycznej. Takie odrzucenie jest propagowane jako właściwe wartościowanie przyrody, podczas gdy koncepcje antropocentryczne są uważane za teoretyczną podstawę eksploatacji i niszczenia przyrody. Jednym z głównym celów niektórych nieantropocentrycznych teorii ekologicznych jest ograniczenie wzrostu populacji ludzkiej, ponieważ jej wzrost jest postrzegany jako przyczyna katastrof ekologicznych i problemów społecznych. Celem tego opracowania jest pokazanie, że istoty ludzkie są w rzeczywistości jedynymi żywymi organizmami na Ziemi, które potrafią dbać o przyrodę tak, jak na to zasługuje. Główny problemem jest niewłaściwy stosunek człowieka do przyrody, nie zaś wielkość jego populacji. Katastrofy ekologiczne są bowiem związane nie tylko z nieodpowiedzialnym postępowaniem człowieka, ale mają także charakter naturalny i są niezależne od aktywności człowieka. Nie zwalniają jednak ludzi z obowiązku wzięcia odpowiedzialności za swoje zachowania środowiskowe.

Słowa kluczowe: etyka środowiskowa, troska o przyrodę, mity ekologiczne 


\section{Introduction}

People's attitude to nature changes strongly after periods of time: from adoration of nature in different pagan cults, to exploitation of it in modern history, then from anthropocentrism to non-anthropocentrism, from the viewing of humans as detached from nature to the viewing of them as merely part of it. The ecological vision just reveals a great actual struggle of diverse worldviews: "The peoples of this planet are now involved in a great civil and ethical struggle, testing which socio-economic and ecological vision of the planetary future will long endure. The importance of this struggle can hardly be overstated, nor its difficulties and dilemmas be over-estimated" (Nash 2000, 227).

Everyone can hear that there is an ecological crisis today. The magnitude of this crisis usually is presented in ecological writings, together with the huge human impact. "The human impact extends across all scales from the local to the global. Over the last 50 years, humanity has moved from being a «small world on a large planet» to becoming a «large world on a small planet»"(Elmqvist et al. 2014, 9) - and this way of presenting the reasons for the environmental crisis, is quite usual in literature. People's activity in modern times is seen as a force that prevails natural capacities: "While humans have always had an impact on their local environment, the changing nature of human societies, and the scale of their impact on ecological systems, has exceeded the carrying capacity of the Earth's atmosphere, land, and water" (Martin et al. 2015, 5).

As in the case of each crisis, there are different ways to solve it. Such ways or proposals, again testify to a great ethical struggle. Environmental ethics, which estimates human relationships with the external world, and the value of the last (Brennan and Lo 2021), is not monolithic, actually, because of the pluralism of concepts and relations between human beings and the environment. The research goal of this article is to make evident that humanity is necessary for nature, because only humanity can evaluate it, and take care about it. Since there are quite different academic views on this point, the thesis has to be analysed. The perspective of the article is philosophical with some theological (mainly Catholic) inserts.

\section{Human-centred and nonhuman-centred environmental ethics}

Environmental ethics exists in two main types: human-centred and nonhuman-centred. The first interprets the natural world as being subordinated to human needs, and requires that the future generations of humans, are not deprived of the environmental goods of the present generations. The second treats the natural world as value, per se, and requires that it is respected, despite its usefulness for humans (Taylor 1986, 10-13). There is, of course, a great difference between both visions of environmental ethics. In human-centred ethics, a human being is seen as a moral subject, who is inevitably responsible for the other moral subjects - fellow humans, and who can also take responsibility for the other living organisms - plants and animals. In the nonhuman-centred ethics, for example, in the life-centred one, not only is a human person treated as a moral subject, but also all living organisms, although not in the sense that they have rights identical to human rights. All living organisms are recognised by the life-centred ethicists to be moral subjects, but not moral agents. Humans, on the other hand, are moral agents - they are able to accept ethical rules and take responsibility for their deeds. Moral agents have duties with regard to moral subjects - plants and animals (Taylor 1986, 13-20).

In other words, human-centred environmental ethics requires from humans, the need to treat carefully the other living organisms, pronouncing that such a careful attitude is useful for people themselves (Barbour 2000, 390). The life-centred or other kinds of nonhuman-centred ethics require from people to take care about plants and animals, because the latter are worthy 
of such care (Taylor 1986, 13). So, anthropocentric environmentalists argue that only human beings have intrinsic value, whilst the non-anthropocentric scientists consider that nature definitely has intrinsic value (Kortetmäki 2013, 24).

Despite the logic of the environmental UN documents, which proclaim that "human beings are at the centre of concerns for sustainable development" (Report of the United Nations Conference on Environment and Development, principle 1; The Future we want. Outcome Document of the United Nations Conference on Sustainable Development, 6), ecology as a science usually rejects anthropocentrism and denies the necessity of human stewardship of nature, consequently (Kryazh 2001, 379). The famous "New Environmental Paradigm" scale, proposed by Riley Dunlap and others, properly suggests seeing in anthropocentrism, the threat for the environment (Brennan and Lo 2021). Even if ecologists take an anthropocentric perspective, they do not take it in a pure form, and reflect on the value of nonhuman beings, separately from their usefulness for people (Barbour 2000, 390). So, today, in scientific circles, there significantly pre-dominates nonhuman-cantered environmental ethics in their different kinds. Human beings are no longer seen as a unique possessor of intrinsic value amongst the natural world, and the human's necessary role in the stewardship of nature, is not obvious anymore. Vice versa, humans are nowadays, often accused of being a threat for the whole natural world: "The current state of the planet suggests what a dangerous mix humanity is, with its prodigious talents, and its enfeebled, ecological, and social conscience. [...] Our species is a threat to all of the foundational elements of life on earth: water, topsoil, and air" (Maguire 2000, 404). If it is true that human conscience is a threat for nature, it is also true for many eco-ethicists that a major quantity of the human species is a threat. Their logic is understandable: more people with their «enfeebled, ecological, and social conscience», more problems with the Earth's eco-system. The excessive quantity of humans is seen to be a cause of destruction of some flora and fauna populations, destruction of wild nature, and a source of the other ecological collapses (Crist and Cafaro 2012, 3).

So, one of the main proposals of many ecologists, is to reduce the world's human population. The reduced number of humans is expected to be, not only a huge advantage for the eco-system, but also the solution to the problem of social poverty: "The limitation of fertility is essential to honouring the earth's carrying capacity and for eliminating poverty" (Maguire 2000, 408). Therefore, the struggle with the human population's growth is represented as a benefit for both the human and nonhuman worlds. As for the relation between the human population's growth and poverty growth, it is necessary to say that even those ecologists, who propagate the limitation of human fertility, recognise that the main cause of increasing poverty is not human over-population, but human over-consumption by people from the developed countries (Maguire 2000, 408; Ehrlich 2012, xiv). So, the linking of quantity and social quality of life of the human race, is ideological rather than scientific. The same indeed is true with the linking of human population growth and ecological disasters.

In the modern world, in which humanism weakens more and more, and "the eco-evolutionary cosmic situation requires a drastic revamping - or even jettisoning - of humanism, and/or Christianity" (Cowdin 2000, 282), it's really important to reflect on the necessity of humanity for nature, on the particular contribution, for which only humanity is able to bring to the wild world.

\section{Human-nature relations}

Making a short excursion on the history of human-nature relations, it should be said that during the Middle Ages, the question of the human stewardship of nature was not given much importance; through the era of capitalism and technological progress, 
the tendency to perceive man as separated from nature intensified, since nature began to be perceived only as a resource to meet human needs. In the modern era, the worldview, in which human beings are separated from nature, is no longer supported either by many theologians or by scientists (Barbour 2000, 391).

First of all, it is crucial to grasp the notion of nature. The concept of nature is fundamental for ecology, and despite the long existence of this, science still now "poses [...] metaphysical, epistemic, and moral problems about the nature of nature, if we can understand it" (Keller and Golley 200o, xi). For a long period of time, nature was perceived by ecologists as "a grand and intricate machine functioning, according to the deterministic Cartesian-Newtonian laws of physics" (Keller and Golley 200o, 17-18), but today, this understanding of nature is not considered far-reaching, "there are additional sources of meaning that the mechanistic approach does not exhaust: the aesthetic, spiritual, and social" (Keller and Golley 2000, 18).

Turning to the question of «the nature of nature», it should be said that there is no agreement, even basic, between the scientists, of what nature is. Some of the scientists affirm that this concept is totally ambiguous: nature is "a word so ubiquitous, yet laden with so many various connotations, that it often hinders clear thinking" (Keller and Golley 2000, 11); "the notion of nature is full of inconsistencies, contradictions, and secrets" (Vogt 2012, 18). According to Markus Vogt, the German theologian, the concept of «nature» is understood within 5 main possibilities: 1 ) the togetherness of all kinds of animate beings; 2) the essence, substance of any animate and inanimate being; 3) the togetherness of all (animate and inanimate) empirically proved beings; 4) reality opposite to human activities, such as culture and techniques; 5) reality opposite to God's being and actions (Vogt 2012, 18-19). Having presented different possibilities to define nature, Vogt recognizes some subjectivity in these efforts: "The correct criterium of «natural» is not given initially, it should be self-defined. A norm in nature is not a kind of general predestination, it is opened order, pre-destinated for interpretation and arrangement. In this meaning, nature is, at the same time, a task for culture", and concludes that "we can't answer on the ethical question about what nature we have to defend" (Vogt 2012, 22). The same idea of real uncertainty of concepts "nature" and "natural" is presented in the works of Helena Siipi, a specialist in applied ethics and environmental philosophy. She affirms: "The terms «natural» and «unnatural» are highly ambiguous, and the success of different arguments appealing to (un)naturalness depends on the exact meanings and interpretations given to them" (Siipi 2003, 246). So, such perplexity, in the concept of nature, only complicates the discussion about the human role in its well-being. In order to avoid some misunderstandings, it has to be said that in this article, under the concept of nature, will be understood the togetherness of all (animate and inanimate) empirically proved beings, according to point 3 of Fogt's proposal ${ }^{1}$.

The role of humanity in relation to nature can be treated in three different ways: 1) humanity is necessary for nature as its steward; 2) humanity is only a part of nature, so is necessary for it, as well as the other living beings, who are necessary; 3) humanity is a danger for nature, so it is better for nature, if humanity was not.

\section{The necessity of humans for nature}

The representatives of the first understanding of the relation between humanity and nature affirm that nature needs human beings, in order to be cared for. It can be heard

1 Despite the proposition to understand here the term of "nature" as togetherness of all empirically proved beings, it should be said that a human being is seen by the author, as more than a part of nature. A human being is not only an animate empirically proved being, but is also a rational and spiritual being, unlike the other empirically proved beings, and due to this, is a part of nature. 
that such thinking is typical of those ecologists, who support the traditional interpretation of the creative biblical narratives, which treat a human person as a crown of creation or place it in the centre of it. Indeed, the idea of human stewardship of nature is asserted by the first book of the Bible: "According to Genesis, humanity is called to till and keep the garden, and to exercise careful stewardship of the earth" (Barbour 2000, 391). In other words, the supporters of such an understanding of human-nature relations, can be accused of having a religious, i.e., not an academic, point of view. However, among the supporters of the idea that nature needs the presence of humanity, there are a number of academic thinkers, and also, other than theologians. One of them is the former Professor of Politics at Princeton University (taught until 2002), George Kateb. First of all, he asserts that human beings prevail over nature, and consequently, human sufferings and needs prevail over the sufferings and needs of the natural world: "In being partly and commendably non-natural, a human being has an incomparably higher status than any animal. If human beings matter more, their suffering matters more" (Kateb 2011, 23). Under the notion of "being non-natural" Kateb understands that a human being possesses some specific characteristics, such as reason, free will, and others that transcend the natural world. As a being partly non-natural, only a human person can understand the value of nature and provide it with necessary care. "The stewardship of nature is a contribution that only humanity can make, and would exemplify human stature, most gloriously. From nature's point of view, even though nature has no point of view, the human species is irreplaceable because its stewardship depends on commendably unique traits and attributes, that help to make human beings partly not natural. Before humanity perished, we could not pass on to any other species, not even our closest relatives, our knowledge and appreciation of nature. Only the partly not natural can serve nature in the certain ways that it deserves and cannot provide for itself" strongly affirms George Kateb (Kateb 2011, 24). The idea of the total necessity of humanity for the natural world is expressed also by John Passmore, an Australian philosopher. He is convinced that despite the fact that nature exists, apart from human interests, its existence is incompatible with the non-existence of humanity. "Any satisfactory philosophy of nature [...] must recognise" - says Passmore, "that the natural processes go on in their own way, in a manner indifferent to human interests, and by no means incompatible with man's total disappearance from the face of the earth" (Passmore 2010, 107).

Also, among theologians, the ideas of human supremacy over nature, and nature's need for a human presence are clearly expressed. Human beings are, at the same time, a part of nature and apart from nature (Deane-Drummond 1996, 70), and "we [human beings] are the only species, which can value beings and systems beyond our own kind for their own sake" (Cowdin 2000, 271).

\section{Humans as a unique part of nature}

The representatives of the conviction that humanity is only a part of nature, seem to have opposite ideas to the previous group of thinkers. To some extent, it is so, because they do not accept human supremacy over nature, but from the other side, they realise, together with the anthropocentric ecologists, that humans are the only moral agents within the physical world. Unlike George Kateb, who considers a human being to be partly non-natural, there are many scientists who consider humans to be wholly natural, to be the part of nature, even if they recognise that human beings possess some characteristics, which cannot be found in the other kinds of nature (Barbour 2000, 388).

So, human persons are seen as a part of the natural world, but the unique part. Unique not in the sense that only humans have intrinsic value, but in the sense that they have some unique characteristics that allow them to judge what is good and what 
is evil, plus to be morally responsible, i.e., to be moral agents. "This planet's biodata, from unicellular to complex creatures, are at least, systemic, interactive, adaptive, renewing, reproductive, and vital forces. [...] As such, they are good for themselves - intrinsic values - in addition to whatever systemic or instrumental values they may provide others. These intrinsic values merit respect from moral agents. By becoming biologically and ecologically informed, we can judge what is good and bad, beneficial and harmful to other living types, and then act, empathetically, to promote their good - indeed, the ecological common good, which is essential also for the human community" - asserts James Nash, ecotheologian (Nash 2000, 236). In the reflections of Nash, the idea that only humans are capable of promoting good for the other living organisms, is well emphasised, which is also for humans' own good. The status of the "moral agent" is, of course, reflective of the moral position, and from this point of view, the human person is morally responsible for nature, even if he/she is a part of it. However, the question of the moral status, in itself, is blurring, today: "At the heart of the new worldview, is the claim that the human species is fundamentally, a function of the earth, which in turn, is a function of the vast cosmological process of the universe. The moral status question, in this perspective, arose at a point when an alienated humanity was attempting to (re)connect with the rest of the world. The new worldview, however, dissolves the barrier between us and the earth, to such an extent, that «moral status» becomes a virtually inappropriate category" (Cowdin 2000, 281-282).

\section{Human threat to nature}

The third group of thinkers on the theme of the human-nature relationship believe that nothing is needed to the natural world, in terms of the human existence. Not only is nothing needed, but there is also nothing good, since humanity with its potential to dominate nature, is the main threat to it. Actually, in this paradigm, is rooted the propaganda to reduce the human population, for the benefit of nature, and from this paradigm, one can mainly draw inspiration from those who accuse humans of all ecological disasters. It is really true that human persons are capable of acting wrongly, and destructively, either in relation to themselves, or in relation to the surrounding world. However, it is not at all true that the very existence of the human race, or its excessive quantity, is a cause of social and ecological problems.

There are enough myths about the human population and its destructiveness to the whole entity of nature. Such scientists as Frances Moore Lappé, Joseph Collins, Peter Rosset, and Luis Esparza, in their collective works, present twelve myths, amongst which, are the following: "There's simply not enough food", "Nature's to blame", "Too many mouths to feed", "Food vs. our environment", "The Green revolution is the answer" (Lappé, Collins, Rosset and Esparza 1998). From the titles of the myths, it is quite easy to understand that these authors perceive the affirmation that over-population is a cause of hunger, poverty, and other problems, to be a myth. They assert: "No country in the world is a hopeless case. Even countries many people think of as impossibly overcrowded, have the resources necessary for people to free themselves from hunger" (Lappé, Collins, Rosset and Esparza 1998, 1); "abundance, not scarcity, best describes the supply of food in the world today. Increases in food production during the past thirty-five years, have outstripped the world's unprecedented population growth" (Lappé, Collins, Rosset and Esparza 1998, 8); "if we believe that famines are caused by nature's vagaries, we will feel helpless, and therefore, excused from action. Learning that famines result from human-made forces, we discover hope" (Lappé, Collins, Rosset and Esparza 1998, 24).

Nobody rejects that there is poverty and hunger in the world, but it is not true that human population growth is a cause of it, as 
well as it is not true that the limits of natural resources or natural conditions are the cause. Regarding the correlation between human population growth and world hunger, it should be stated that the statistics strongly reject links between both, because of the fact that the rate of human deaths from famine, declines despite population growth. "It is clear that contra Malthus's first Essay and his disciples, who continue to argue that famines are associated with over-population, an increase in world population has been associated with a decline in famine deaths. There are several plausible reasons why more people means lower risk of dying in famine. Among them is the economic development that has accompanied population growth in modern times. Another element, associated with population dynamics themselves, is the demographic transition", affirms Alex de Waal (De Waal 2018, 190-191), researcher and Director of the World Peace Foundation. The other reasons, for which the rate of deaths from famine reduces, in the mind of De Waal, should be found in the «Green Revolution», and the increase in food production (De Waal 2018, 191). Indeed, as it was already mentioned in the work of Lappé and others, the statistics testify that the increase in food production prevails significantly, upon the increase in population (Patel 2013, 6). So, the thesis that the lack of natural resources causes poverty and hunger, is not true. The cause should be searched in human behaviour, and not in human quantity or natural conditions.

Recent history clearly shows that the main cause of famines is rooted in human politics. That is what Alex de Waal says about this: "The second half of the twentieth century demonstrated that with the required political demands and calculations, calamitous famines could be entirely eliminated, and the threat of mass starvation reduced to a shadow of its former self. This under-acknowledged triumph was consolidated by a global humanitarian norm and associated infrastructure. That progress can be resumed. Famine can indeed be ended" (De Waal 2018, 194). Regardless of the facts, the idea that human population growth causes poverty and hunger, remains most powerful in human society: "Despite the negative correlation between famine deaths and growing population, the most popular explanation for famine remains the over-population argument. Like a zombie, this concept resists being killed by evidence and logic, and repeatedly returns to plague the living" (De Waal 2018, 191). Even if not recognised, the truth remains that human politics and everyday conduct are powerful factors in social crises. The same is true about ecological crises.

First of all, it should be recognised that ecological crises are not a result, exclusively, of human activity. There are some natural disasters that change and challenge an environment (Hastings and Cross 2012, Preface). For example, it is a serious question, whether global warming is a result of human activity. There are scientists that see a connection between global warming and the activity of the Sun (Deane-Drummond 1996, 80), and not the activity of humanity. This is absolutely logical if you take into consideration the fact that the role of the Sun is fundamental for the Earth's climate (Haigh and Cargill $2015,1)$. Also, the extinction of some kinds of animals and plants has other reasons than the human factor, which is proved by such a fact that extinction is not a new phenomenon, that it appeared in the epoch of human progress. Some organisms died out, for example, in the Pleistocene epoch. Undoubtedly, there were serious biological factors behind the extinction (Vermeij 1986, 30). Further back before the Pleistocene epoch, and even the most massive in history was the extinction in the Permian period. American paleobiologist, Douglas Erwin, writes about the striking consequences of two Permian crises: "Between the rocks in Texas and Utah, the Earth experienced two great crises, some 10 million years apart. These twin disasters extinguished nine out of every ten species in the oceans. Moving up the taxonomic hierarchy to more inclusive groups, 
about $82 \%$ of genera, and fully half of all marine families, disappeared, a level of extinction that dwarfs any of the other great mass extinctions. As many marine families were wiped out during this event, as the next two largest mass extinctions combined. Each of these Permian events alone, was greater than the extinction that killed off the dinosaurs. Together the twin crises form the greatest biotic catastrophes of the past 543 million years" (Erwin 2006, 7). So, the main biotic catastrophes occurred absolutely without human impact. The same applies to other mass extinctions of ancient times. This naturally leads one to think that the human factor in mass extinctions is by no means the most powerful.

When discussing the human factor in an ecological crisis, it is a moral factor, and not ontological. The morality of humans can be a threat to nature, but not their existence. Human responsibility has to be stressed, and not human population growth. "The most fundamental challenge for achieving ecological security is the development of a global culture of ecological responsibility" - affirms Patricia Mische, a specialist in Peace Studies and Law, co-founder of Global Education Associates (Mische 2000, 592). Mische continues, saying that every person has to take responsibility, and through inner governance promote the health of nature (Mische 2000, 592). The role of religions, in particular Christianity, to the mind of Mische, is considerable in the development of this inner governance (Mische 2000, 592-593).

The special role in the forming of morally correct behaviour regarding the environment, belongs to education in families and educational institutions of all levels. Environmental ethics has also to be discussed in economic, political, and administrative circles. The task is to educate each person to be responsible for nature (Vogt 2012, 15). In addition, literature and different arts can, and have to educate human generations, to build authentic relations to nature, as well as the media of all types, has to be a rich source of reliable environmental education, and not only information. If humans learn to be truly responsible for their personal, social, and environmental choices, their large quantity will be only good for nature, and not a danger.

\section{Conclusion}

Ecology cannot be perceived as a descriptive science, it is impossible for ecologists to "escape making value judgments about nature. Ecology entails ethics" (Keller and Golley $2000,18)$. In the modern world with its moral pluralism, there are two kinds of environmental ethics: human-centred and nonhuman-centred. The differences between both are crucial: the first attributes the intrinsic value only to humans, whilst the second - also to the other kinds of nature. In this paradigm of two parallel branches of environmental ethics, the question of what the relation between humanity and nature is, and what is (if it is) the specific role of humanity in the eco-system, receives quite different answers. Human-centred ecologists will reply that the human community is necessary for nature, because nature needs to be stewarded and esteemed by humans. It is true that humanity needs the land and its resources, but also the land needs humanity, because only humanity can value the land: "We not only need the land, but are capable of respecting it as such" (Cowdin 2000, 271). Some nonhuman-centred ecologists will also recognise the unique role of humans for nature, even if humans are considered to be only a part of it (humans are the moral agents, while the other living organisms are the moral subjects; the moral agents are able and are called to act on behalf of the moral subjects). Yet, there are also nonhuman-centred ecologists who deny the unique role of humanity in the existence of the eco-system and believe that the mere existence of humanity is a problem for nature, in particular, if humanity grows in terms of numbers. Such ecologists accuse humanity of all ecological disasters, and constantly require the reduction of the human population. Such reduction is necessary, to their minds, 
not only for the sake of nature, but also for the sake of humanity, itself, since they see a causal connection between the population growth and poverty. "A finite earth cannot hold infinite numbers" (Maguire 2000, 408) is their logical statement. The truth is, however, that ecological disasters have other serious casual factors, apart from the human factors, and that social problems are caused by overconsumption and inadequate politics, much more than by overpopulation.

To attribute to humanity, the total or main responsibility for the climate changes on the Earth, or for the extinction of different plants and animals, is too courageous or mythical, in other words. Such attribution does not count the existence of natural forces, uncontrolled by people, and more influential than people, in the sense of power to change the face of the Earth. We are talking, first of all, about the Sun. Whose power to cause global warming is the stronger: the Sun, with its radiating activity, or of humans with their technical activity? Also, there is one more important question: whose power to cause the extinction of some kinds of flora and fauna on the oceanic or sea bottoms is stronger: human or nonhuman? And was it human power that made large mammals in the Pleistocene epoch (Vermeij 1986, 30), die out? Of course, there are such flora and fauna extinctions, or other ecological disasters, that are the results of human irresponsible conduct, but one cannot deny the fact that humans are not the causers of all ecological crises.

In reality, human beings are the only physical living beings on the Earth, who are capable of taking care about nature. If we imagine that the drastic climate or other natural changes occurred in these times and did not happen in the Pleistocene epoch or Permian period, it is very likely that people would have preserved in some artificial conditions, large mammals or other species of living organisms. Nature is incapable of taking take care of itself; humanity is capable of providing it with such care. So, each ecological theory that denies the unique role and necessity of humanity for nature, denies at the same time, the value of nature. Nature deserves to be cared for, even if its value is instrumental, and not intrinsic. Only a human being is able to take care of nature. $\mathrm{Na}$ ture cannot be cared for by itself - unlike humans, it is not conscious and cannot take responsibility.

Are human beings a threat to nature? They can be, and often they are, but they must not be. The wrong conduct of some people regarding nature cannot be the cause of generalisation and attribution to all people of the accusation of being dangerous to nature. Nonhuman-centred ecology is indeed dangerous to nature, because it denies the responsibility of humans for nature. The same term "ecology" loses its sense, since if ecology is "the scientific study of the earthly dwelling place" (Keller and Golley 2000, 9) (due to the etymology of the term), so it pre-supposes that there is somebody, who has an Earth as home, who is a master of this home-house. Who can be the master of unconscious nature, if not the conscious human race?

The Earth is able to be the dwelling place for the huge human population, but only on condition that human beings change their priorities and lifestyles (Deane-Drummond 1996, 137). Human beings are called upon to take care of nature and not to destroy it. They are required to use nature for their own sake, but also to serve nature for its sake. It is possible to use nature, and to serve it at the same time, as it is possible to use one's house and serve it for its preservation. So, the main task of ecology is to convince people to take responsibility for nature, and not to convince people to treat themselves, just as a part of unconscious, and therefore, irresponsible nature. Even if there are the weak sides to the humanistic approach, nevertheless humanism "protects us from conceptual absurdity and the political spectre of eco-fascism" (Cowdin 2000, 264). Eco-fascism is not only destructive for humans, but also for nature. 
Funding: This research received no external funding. Institutional Review Board Statement: Not applicable.

Conflicts of Interest: The author declares no conflict of interest.

\section{References}

Barbour, Ian G. 2000. "Scientific and Religious Perspectives on Sustainability." In Christianity and Ecology. Seeking the Well-Being of Earth and Humans, edited by Dieter T. Hessel and Rosemary Radford Ruether, 385-401. Harvard University Press.

Brennan, Andrew and Yeuk-Sze Lo. 2021. "Environmental Ethics." In The Stanford Encyclopedia of Philosophy (Winter 2021 Edition), edited by Edward N. Zalta. Accessed November 02, 2021. https://plato.stanford.edu/entries/ ethics-environmental/.

Cowdin, Daniel. 2000. "The Moral Status of Otherkind in Christian Ethics." In Christianity and Ecology. Seeking the Well-Being of Earth and Humans, edited by Dieter T. Hessel and Rosemary Radford Ruether, 261-290. Harvard: Harvard University Press.

Crist, Eileen, and Philip Cafaro. 2012. "Human Population Growth as If the Rest of Life Mattered." In Life on the Brink. Environmentalists Confront Over-population, edited by Philip Cafaro, Eileen Crist, 3-15. Athens - London: The University of Georgia Press.

Deane-Drummond, Celia. 1996. A Handbook in Theology and Ecology. London: SCM Press Ltd.

De Waal, Alex. 2018. "The end of famine? Prospects for the elimination of mass starvation by political action." Political Geography 62: 184-195. doi:10.1016/j.polgeo.2017.09.004.

Ehrlich, Paul, and Anne Ehrlich. 2012. "Foreword." In Life on the Brink. Environmentalists Confront Over-population, edited by Philip Cafaro, Eileen Crist, xi-xiv. Athens - London: The University of Georgia Press.

Elmqvist, Thomas, Sarah Cornell, Marcus C. Öhman, Fredrik Moberg, Albert Norström, Åsa Persson, Garry Peterson, Johan Rockström, Maria Schultz, and Ellika Hermansson Török. 2014. Global Sustainability \& Human Prosperity - contribution to the Post-2015 agenda and the development of Sustainable Development Goals. Copenhagen: Nordic Council of Ministers.

Erwin, Douglas H. 2006. Extinction. How Life on Earth Nearly Ended 250 Million Years Ago. Princeton - Oxford: Princeton University Press. Haigh, Joanna D., and Peter Cargill. 2015. The Sun's Influence on Climate. Princeton - Oxford: Princeton University Press.

Hastings, Alan, and Louis J. Cross (eds). 2012. Encyclopedia of Theoretical Ecology. Berkeley - Los Angeles - London: University of California Press. Kateb, George. 2011. Human Dignity. Cambridge - Massachusetts - London: The Belknap Press of Harvard University Press.

Keller David R., and Frank B. Golley (eds). 2000. The Philosophy of Ecology. From Science to Synthesis. Athens, Georgia: University of Georgia Press.

Kortetmäki, Teea. 2013. "Anthropocentrism versus Ecocentrism Revisited: Theoretical Confusions and Practical Conclusions". Northern European Journal of Philosophy, 14(1): 21-37. doi:10.1515/ sats-2013-0002.

Lappé, Frances Moore, Joseph Collins, Peter Rosset, and Luis Esparza. 1998. World Hunger: 12 Myths, second edition. London: Earthscan.

Maguire, Daniel C. 2000. "Population, Consumption, Ecology: The Triple Problematic”. In Christianity and Ecology. Seeking the Well-Being of Earth and Humans, edited by Dieter T. Hessel and Rosemary Radford Ruether, 403-427. Harvard University Press.

Martin, Aran, Kazuki Kagohashi, Michael T. Seigel, John Pullen, Christian Dimmer, Kazuyo Nagahama, and Winibaldus S. Mere. 2015. Responding to the Environmental Crisis. Nagoya: Nanzan University Institute for Social Ethics.

Mische, Patricia M. 2000. "The Integrity of Creation: Challenges and Opportunities for Praxis." In Christianity and Ecology. Seeking the Well-Being of Earth and Humans, edited by Dieter T. Hessel and Rosemary Radford Ruether, 591-602. Harvard University Press.

Nash, James A. 2000. "Seeking Moral Norms in Nature: Natural Law and Ecological Responsibility." In Christianity and Ecology. Seeking the Well-Being of Earth and Humans, edited by Dieter T. Hessel and Rosemary Radford Ruether, 227-250. Harvard University Press. 
Passmore, John. 2010. "Attitudes to Nature." In Environmental Ethics. The Big Questions, edited by David R. Keller, 103-110. Chichester: Wiley-Blackwell.

Patel, Raj. 2013. "The Long Green Revolution". The Journal of Peasant Studies 40(1): 1-63. doi:1 0.1080/03066150.2012.719224.

Siipi, Helena. 2003. "Human Genetics and the Statement of Unnaturalness." Trames. Journal of the Humanities and Social Sciences 7(4): 237-248.

Taylor, Paul W. 1986. Respect for Nature. A Theory of Environmental Ethics. Princeton: Princeton University Press.

United Nations. 2012. The Future we want. Outcome Document of the United Nations Conference on Sustainable Development. Rio de Janeiro, 2022 June, 2012. Accessed November 02, 2021. https://sustainabledevelopment.un.org/content/ documents/733FutureWeWant.pdf.

United Nations. 1992. Report of the United Nations Conference on Environment and Development. Rio de Janeiro, 3-14 June, 1992. Accessed November 02, 2021. https://www.un.org/en/development/ desa/population/migration/generalassembly/
docs/globalcompact/A_CONF.151_26_Vol.I_ Declaration.pdf.

Vermeij, Geerat J. 1986. “The Biology of HumanCaused Extinction." In The Preservation of Species. The Value of Biological Diversity, edited by Bryan G. Norton, 28-49. Princeton: Princeton University Press.

Фогт, Маркус. 2012. Экологическая этика. Место человека в природе: сборник материалов проф. Маркуса Фогта. УжгороА: Карпатская вежа [Vogt, Markus. 2012. Ekologicheskaya etika. Mesto cheloveka v prirode: sbornik materialov prof. Markusa Vogta. Uzhgorod: Karpatskaya vezha].

Кряж, Ирина В. 2001. “От антропоцентризма к биоцентризму: о возможности смены парадигмы”. In Фимософия әкологического образования, edited by Игорь К. Аисеев, 379-384. Москва: Прогресс-Традиция [Kryazh, IrinaV. 2001. "Ot antropotsentryzma k biotsentryzmu: o vozmozhnosti smeny paradygmy”. In Filosofiya ekologicheskogo obrazovaniya, edited by Igor K. Liseev, 379-384. Moskva: Progress-Traditsiya]. 